\title{
絶滅危惧植物フジバカマの種子発芽特性および 埋土種子集団の形成可能性
}

\section{Seed Germination Traits and the Potential for Soil Seed Bank Formation of a Threatened Plant, Eupatorium japonicum Thunb.}

\author{
本田裕紀郎 ${ }^{*}$ 伊藤 浩二* 加藤 和弘* \\ Yukio HONDA Kouji ITOH Kazuhiro KATOH
}

\begin{abstract}
Although Eupatorium japonicum Thunb. is a threatened plant species in Japan, conservation ecological studies on it have not been enough for conservation practices. Conservation of threatened plant species requires information on seed germination and soil seed bank. In the present study, we conducted germination tests with gradual temperature method (GTM) considering the light conditions, aiming to evaluate the expression of physiological traits contributing to accumulate their seeds into soil seed banks. We also tried to germinate the seeds contained in the soil that was sampled within a habitat of this species in order to detect the soil seed bank. We found no germination traits contributing to accumulate their seeds into soil seed banks. We also could not detect their seeds in the soil within its habitat. We concluded that this plant does not have the mechanisms for soil seed bank formation. Therefore, if all of above-ground local populations will become extinct, it means extinction of this plant's metapopulation. As we can not rely on soil seed banks for population restoration, our immediate task is to conserve the existing individuals and their habitats. When we should conduct the restoration of this plant, it is effective enough to disperse their cold-stratified seeds before the beginning of spring.
\end{abstract}

Keywords: soil seed bank, seed germination traits, threatened plant, Eupatorium japonicum Thunb., conservation キーワード：埋土種子集団，種子発芽特性，絶滅危惧植物，フジバカマ，保全

1.はじめに

フジバカマEupatorium japonicum Thunb.はキク科ヒヨドリ バナ属の多年生草本であり, 関東地方以西の日本抢よび朝鮮半島, 中国大陸に分布し，河岸の湿った草地に生育する ${ }^{29)}$ 。本種は秋の 七草の一種であるほか，万葉集を初めとした多くの古典作品にも 登場し, 我が国においては古くから親しみのある植物種であった。 しかしながら, 絶滅危惧 II 類に分類される ${ }^{18)}$ ほどにその分布状況 は乏しく ${ }^{14)}$ ，絶滅が懸念されているにもかかわらず，本種に関す る保全生態学的な研究例は, 全国での生育状況抢よび生育地の特 性 ${ }^{14)}$ および地上部の喪失に対する生長反応 ${ }^{46)}$ のみである。

種子植物における保全生態学的研究の現場では, 種子発芽およ び埋土種子集団に関する情報は不可欠なものである ${ }^{30,33) 。 そ れ は ， ~}$ 永続的埋土種子集団の形成は時間的に予測不能な擋乱に対する進 化的な特性であり, 環境の不確実性から個体群を保護する緩衝作 用として機能し ${ }^{5,6)}$ ，個体群の成長率が至しい場合にもその安定性 をむたらすことによる ${ }^{19,20)}$ 。逆に，永続的埋土種子集団の欠如は， 地上部の局所個体群の全てが一旦でも絶滅するとメ夕個体群の絶 滅を意味することになる ${ }^{56)}$ 。さらには, 保全生態学的研究やその 指針にもとづく保全・復元事業においては, 種子や埋土種子集団 が材料として利用される場合が多いためであある ${ }^{52)}$ 。これらのこ とは, 頻繁な増水により植生が繰り返し破壊されることにより維 持されてきた河川生態系に扔いて植物種を保全する際にも同様で あり, 埋土種子集団を含めた個体群の現状や動態に関する健全な 知見に基づいて管理が行われなければならない垃。しかしながら， 本種においては埋土種子集団の形成可能性を含めた種子発芽特性 に関する基礎的な知見は得られていない。

生態学に扔いては長らく種子の休眠が埋土種子として存続させ る機構であると考えられてきたものの, 休眠と埋土種子集団の関 連性は薄いことが近年になって報告されている ${ }^{41,45)}$ 。しかしなが ら，植被の下で無駄な発芽を回避するための「ギャップ検出機構」
は埋土種子集団を形成する機構であると依然として考えられてい $3^{41)}$ 。それに加え, 発芽速度が極めて遅いことによる「発芽の長 引き」11) も埋土種子集団の形成に寄与すると考えられている。そ こで, 本研究においては, 多くの種子植物において報告されてい る主要なギャップ検出機構である変温要求性 ${ }^{11,43,44)}$, 光要求 性 $^{10,11,34,48,49)}$, 緑陰効果感受性 ${ }^{9,21,38,50)}$ に着目し, これらの発現の有無 を試験するとともに，本種の基本的な発芽特性を明らかにするこ とを目的とした。な拝，本種の散布体は厳密には「瘦果」である あのの，便宜上「種子」で統一する。

\section{2. 研究方法}

（1）採集種子を用いた段階温度法（GT 法）による発芽試験

本種の種子を 2003 年 10 月 25 日に利根川水系の小貝川から採 集し，室温にて約 7 ヶ月間保存したものを発芽試験に供試した。 本種は鑑賞のため栽培されたものがしばしば逸出しているものの, 利根川流域および淀川流域の生育地は確実に野生である

まず，低温湿潤処理の要求性を試験するための予備試験を行っ た。その結果，上記の種子集団においては低温湿潤処理を施さず と屯発芽が確認された。そこで，本研究においては低温湿潤処理 を施さずに GT 法 ${ }^{511}$ による発芽試験を行った。GT 法は温度条件 に対する発芽の挙動を試験するための簡便法であるものの，この 手法は発芽試験に用いる種子数が比較的少量であっても, 特定の 温度域に扔ける休眠の解除および誘導, 非休眠種子の発芽可能な 温度域および最適発芽温度, 発芽に要する時間などの多くの有益 な知見が得られる ${ }^{51,53)}$ 。本種は絶滅の懸念される種であり，多量 の種子を用いて研究を行うべきではないことから，比較的少数の 種子により発芽特性に関する知見を最大限得られるようこの手法 を用いた ${ }^{51)}$ 。GT 法は，段階的に温度を上昇させる温度上昇系 （IT 系）および段階的に温度を下降させる温度下降系（DT 系） を設定し，その 2 つ系における発芽傾向を比較する発芽試験法

*東京大学大学院農学生命科学研究科 
である。本試験において設定した夕イムコースを表一 1 に示す。 これはGT 法を用いた先行研究と同等であり ${ }^{16,26,27,3,3,37,51,55)}$, 発芽速 度は生理学的な範囲内においては一般的に高い温度において速い ため, 高い温度においては短い試験時間が設定されている ${ }^{51)} 。$

これらの 2 つの温度変化コースに対して光条件をそれぞれ 3 種 類設定して，発芽試験を行った。それらは，1）暗条件：シャ一 レの全面にアルミホイルを 2 重に巻いたもの, 2 ) 緑葉透過光下 条件：シャーレの底面抢よび側面にアルミホイルを 2 重に巻き, 天面にはクズ Pueraria lobata (Willd.) Ohwi の葉を 2 重に巻 いたもの，3）明条件：上記の処理を施さない通常のシャーレと した。これらの光条件は, 光要求性打よび緑陰効果感受性の有無 を試験するためである。種子レベルに打ける光合成有効波長域の 光量子密度 (PPFD) は明条件で $31.2 \mu \mathrm{mol} \mathrm{m}^{-2} \mathrm{~s}^{-1}$ であり, 緑 葉透過光下条件㧍よび暗条件に㧍ける光透過率はそれぞれで 3.2

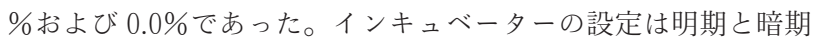
の 12 時間交代とした。なお, 变温要求性においては, IT 系の 36 ${ }^{\circ} \mathrm{C}$ 恒温条件に続いて $12 / 25^{\circ} \mathrm{C}$ 变温条件を 5 日間経験させることに より，その性質の有無を試験した。IT系における交代温度も 12 ${ }^{\circ} \mathrm{C}$ (暗期) および $25^{\circ} \mathrm{C}$ (明期) のそれぞれ 12 時間交代とした。

シャーレには種子を 30 粒ずつ置床し, 各条件につき 3 反復で 発芽試験を行った。そのため, 発芽試験に用いた種子数は 540 粒 (温度 $2 \times$ 光 $3 \times$ 種子数 $30 \times$ 反復数 3 ) である。全ての条件区に おいて, 直径 $5.5 \mathrm{~cm}$ のプレスチックシャーレに石英砂 $15.0 \mathrm{~g}$ を敷 き詰めたものを発芽床とした。また, シャーレ内には蒸留水を適 宜給水しながら, 発芽試験を行った。発芽数の計測は, 表一 1 に 打けるそれぞれの設定温度を変更する直前に行い, 種皮からの幼 根の突出をむって発芽と見なした。な押, 暗条件抢よび緑葉透過 光下条件に扔いては, 暗室に扔いてグリーンセーフライトを用い て計測を行った。その際, 発芽した個体はシャーレ内から除去し た。

\section{(2) 統計的検定}

熟谷 ${ }^{53}$ に倣い, IT 系における $12 / 25^{\circ} \mathrm{C}$ 変温条件および DT 系 に打ける $25^{\circ} \mathrm{C}$ 恒温条件を経験した後の累積発芽率を「最大発芽 率」，その直前までの累積発芽率を「最終発芽率」と呼ぶ。

光条件の効果に扔いては, IT 系と DT 系のともに, 明条件を 対照群, その他の光条件を処理群として, それぞれの最終発芽率 を用いて Dunnett 法による多重比較を行った。ここでの familywise な第 1 種の過䛊率は 0.05 とした。この手法を用いた理由は, 暗条件と緑葉透過光下条件抢よび明条件と緑葉透過光下条件での 最終発芽率を両方之も比較することに生物学上の意義が無く, こ の場合に Tukey 法などのように全ての組み合わせにおける有意 な差を探索する unplanned comparison を行うと, 個々の比較 における第 2 種の過䛊率が無意味に上昇するためである ${ }^{35)}$ 。

温度条件の効果に抢いては, 明条件に打ける IT 系之 DT 系の 最終発芽率を用いて $t$ 検定にかけた。さらに IT 系とDT 系のそ れぞれに扔いて, 光条件ごとに, 最終発芽率と最大発芽率を用い て $t$ 検定にかけた。IT 系の結果からは变温要求性の有無を, DT 系の結果からは低温による休眠解除の有無を知ることができる。 な㧍, 個々の $P$ 值は sequential Bonferroni 法を用いて familywise な第 1 種の過䛊率を調整しこここであそれは 0.05 とした。 この方法を用いた理由は上記と同様である。なお，統計的検定に 先立って, 全ての累積発芽率の值には逆正弦变換を施した。

\section{（３）土壌サンプルを用いた撒き出し試験}

翼や冠毛のような風散布のためのしかけの有無に関わらず, 種 子は一般に母植物の付近に最屯高密度に散布される $3^{8,24,36,39,47)}$ 。そ こで, 2004 年 7 月 18 日に, 上述の発芽試験に用いた種子を採集 した本種個体から半径 $1 \mathrm{~m}$ 以内の表層土袞を 3 地点から採取した。 採取方法は, 1 地点加らそれぞれ面積 $10 \times 10 \mathrm{~cm}$, 深さ $2 \mathrm{~cm}$ 表

\section{表－1 GT 法発芽試験における設定温度とその温度变化のタイ ムコース}

\begin{tabular}{|c|c|c|c|c|c|c|c|c|c|c|}
\hline 温度 $\left({ }^{\circ} \mathrm{C}\right)$ & 4 & 8 & 12 & 16 & 20 & 24 & 28 & 32 & 36 & $12 / 25^{\circ} \mathrm{C}$ 変温 \\
\hline 日数 & 8 & 5 & 4 & 3 & 2 & 2 & 2 & 2 & 2 & 5 \\
\hline \multicolumn{11}{|l|}{ DT系 } \\
\hline 温度 $\left({ }^{\circ} \mathrm{C}\right)$ & 36 & 32 & 28 & 24 & 20 & 16 & 12 & 8 & 4 & $25^{\circ} \mathrm{C}$ 恒温 \\
\hline 日数 & 2 & 2 & 2 & 2 & 2 & 3 & 4 & 5 & 8 & 5 \\
\hline
\end{tabular}

層土畩をそれぞれ 5 箇所ずつ採取した。（それぞれ計 $1000 \mathrm{ml} ） 。$ この時期に採取した理由は, 後述するように GT 法による発芽試 験の結果より, 春に発芽していると推定されることから, 発芽季 節が終了した季節の土壤を採取することにより, 永続的埋土種子 集団の存在を調査するためである。この目的のためには, 厳密に は発芽季節の前後で種子密度を比較することが必要であるが ${ }^{1,13,566}$, 土壤中の種子を多量に消費しか㸚ないために倫理的な問題がある。 そこで, 本試験においては, 発芽季節前には種子が含まれていた 可能性が最も高いと推定される, 前年に種子生産を行った個体付 近の土壌を, 発芽季節後に採取して撒き出した。撒き出しにより 発芽個体が得られなかった場合，フジバカマが永続的埋土種子集 団を形成しない可能性が推定されるが, 撒き出した土袞にもとも と種子が含まれていなかった可能性すあることに留意しなければ ならない。表層土壌を採取した理由は, 前年に生産された種子は 表層部分にのみ存在しえること,さらには土㙵の深さに応じて埋 土種子集団の密度は減少するためである

埋土種子の構成種を調査する方法には数種類存在するものの, $\operatorname{Gross}^{12)}$ は, 埋土種子を土㙵中から発芽させて測定する方法（出 現実生法）が，種の同定のしやすさと生死の判別のしやすさから， 最む優れていると結論しているため, 本調査ではこの方法を採択 した。まず，採取した土壤中の混入している植物体を除去するた めに本種の種子よりも大きな $2.5 \mathrm{~mm}$ メシュのふるいにかけた後 に，アルミホイルを敷き詰めた $20 \times 27.5 \mathrm{~cm}$ のプラスチック製の バスケットに約 $1.5 \mathrm{~cm}$ の厚さで敷き詰め, その土壤内の種子をイ ンキュベーター内で発芽させた。インキュベーターの設定温度は, $4{ }^{\circ} \mathrm{C}$ での低温湿潤処理を 7 日間施した後, $22^{\circ} \mathrm{C}$ の恒温条件とした。 それは, 後述するように GT 法による発芽試験結果から推定され た最適な発芽温度が約 $22^{\circ} \mathrm{C}$ であったためである。

発芽した個体は, 実生の段階で本種以外の種であると判断され た個体は除去し，本種の個体と疑われる種においては，同定可能 な段階まで生長させた。得られた本種の個体数をむって, 土壌中 に含まれていた本種の種子数の推定值とした。さらに, 撒き出し における土袞厚に依存した出現実生数の減少 ${ }^{7)}$ を抑制するために, 発芽した実生を全て抜き取った後に，土㙵を改めてふるいにかけ 攪拌し，低温湿潤処理を除いた同様の手順で改めて発芽させた。

\section{3. 結果}

GT 法に扔ける発芽試験結果を図ー 1 に示す。IT 系に扔いて は $12{ }^{\circ} \mathrm{C}$ から，DT 系に扔いては $32^{\circ} \mathrm{C}$ から発芽が確認された。そ のため, 打よそ $12-32^{\circ} \mathrm{C}$ という幅広い発芽可能な温度域をむつ ことが示唆される。また, その中央值である $22^{\circ} \mathrm{C}$ 付近が本種の 発芽の最適温度であると推定される。DT系に扔いては，4 日目 から発芽が確認され, 発芽に要する日数は短かった。明条件下に おけるIT 系抢よび DT 系間の最終発芽率には差が確認されない ため $\left(t\right.$ test, $\left.t_{4}=1.5391, P>0.05\right)$, 特定の温度域における二 次休眠の誘導および完全な非休眠種子と比較して発芽可能な温度 域が狭まった状態の相対的休眠 ${ }^{3)}$ の存在は見出されなかった。さ らに，IT系と DT 系のともに，明条件抢よび暗条件間に扔いて $(P>0.05)$, さらに明条件抢よび緑葉透過光下条件間において $(P>0.05)$ 有意差は確認されなかった。IT 系の最終設定温度で 


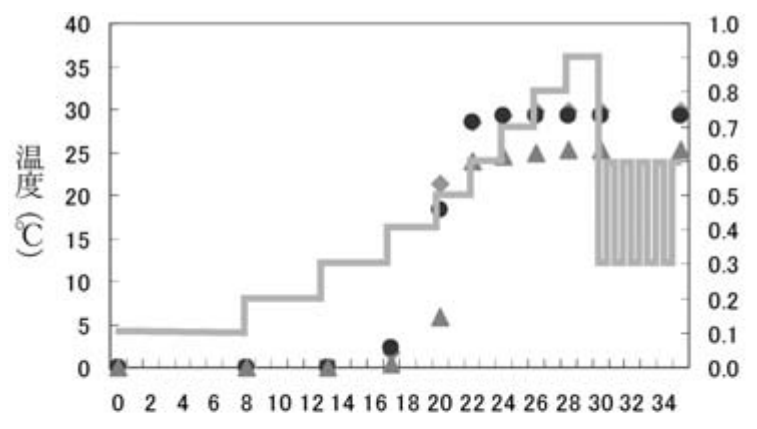

蘶
発
臯
$\%$
$\%$

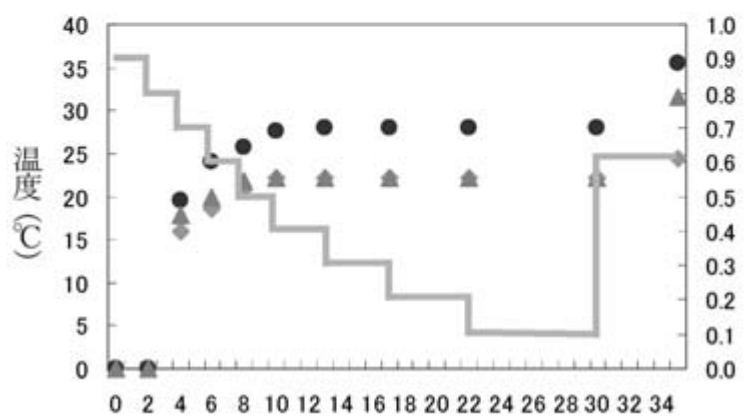

日数

\section{図－1ＧT 法による発芽試験結果}

上図：IT 系, 下図：DT 系。 : 明条件, $\boldsymbol{\Delta}$ : 緑葉透過光下条 件, ○：暗条件。階段状の直線は設定温度を示す。

ある $12 / 25^{\circ} \mathrm{C}$ の交代温度は上述の通り発芽可能な温度域であるも のの, 最大発芽率は最終発芽率から上昇しなかった。そのため, 発芽に抢ける光要求性, 緑陰効果感受性抢よび変温要求性の全て を本種はもたないことを示唆している。DT 系の最大発芽率は, 全ての光条件に扔いて最終発芽率から上昇しているものの, 暗条 件においてのみそれは有意であった $(P<0.001)$ 。そのため, 本 種の種子には若干の低温要求性が認められる。

土壌サンプルの撒き出し試験の結果, 種子密度が最む高くなる と考えられる, 前年に種子生産を行った個体付近に打ける表層土 壌からも, 発芽季節後には本種の種子は検出されなかった。

\section{4. 考察}

本種の種子は晚秋に生産され, そして若干の低温要求性が認め られる。一般的に, 種子の内生休眠は発芽に打ける季節選択の機 構としては明瞭であるものの, 種子の休眠と埋土種子集団の形成 との関係性は薄い(11,45)。そのため, 冬の低温により解除される種 子の内生休眠は春に発芽するための季節選択の機構であり, 埋土 種子集団の形成には寄与しないと考えられる。また, 特定の温度 域において二次休眠も誘導されないことから，本種の野外におけ る発芽時期は翌春であると考えられる。

本種は河川の汇濫原に代表的に生育する植物種である ${ }^{14)}$ 。 Thompson ほか2(2) は, 擋乱頻度の高いハビタットに生育する植 物種ほど永続的埋土種子集団を形成する傾向にあることを示唆し ている。しかし, 河川は増水による擋乱を頻繁に受ける八ビタッ トであるものの, 本種は永続的埋十種子集団の形成に寄与するギャッ プ検出機構41)をもたないことが示唆された。これは, 丸石河原と 呼ばれる擋乱頻度の著しく高い環境に生育し ${ }^{15,23,40)}$ ， しかも河原 以外には生育地をもたないカワラノギクAster kantoensis Kitam. 拉よびカワラニガナIxeris tamagawaensis Kitam. ${ }^{22)}$ に おいてもギャップ検出機構をもたない因,56) という点で共通してい る。また, 発芽速度が極めて遅いことによる「発芽の長引き」屯 確認されなかった。特定の温度域による二次休眠の誘導 ${ }^{2)}$ は埋土
種子集団形成に寄与すると考えられている場合ああるものの，そ のような生理的反応む確認されなかった。

加えて, あとあと種子が含まれていなかった可能性ああるあの の，前年に種子を生産した個体付近の土㙵中に扔いても発芽季節 後には種子が含まれていなかったことから, 発芽試験の結果之併 せて本種が永続的埋土種子集団を形成する性質をむたないことを

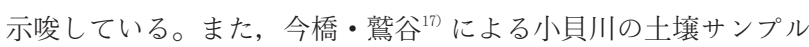
の撒き出し試験においても, 本種の種子は検出されていない。そ のため, 約 $12^{\circ} \mathrm{C}$ から $32^{\circ} \mathrm{C}$ まで幅広い発芽可能な温度域をむつ ことからも，水分および温度条件さえ整えば直ちに発芽し，春の 訪れ之ともにほぼ全ての種子を発芽させていると考えられる。

本種は永続的埋土種子集団を形成する生理的性質をむたないた め, 新たな局所個体群の創出は残存する生育適地への種子分散に 頼らざるを得ない。その場合, 埋土種子集団を形成する種と比較 して, 生育適地の減少はより致命的になる。しかしながら, 発芽 のセーフサイトに関する研究は行われておらず, 今後の課題であ る。さらには, 永続的埋土種子集団の欠如は, 地上部の局所個体 群の全てが一旦でも絶滅するとメ夕個体群の絶滅を意味すること になり ${ }^{56)}$ ，本種においては地上植生中の個体および生育地を最大 限保全することが当面の目標となる。

埋土種子集団を形成することは，生産年の異なる種子集団を蓄 積することによる遺伝的変異の保有効果が期待され, それらを用 いた植生復元により遺伝的多様性の高い個体群を創出することが 可能であるものの，本種においてはそれを期待することはできな い。今後, カワラノギクの例のように, 本種に扔いても個体群復 元事業を行う必要性がある場合には, 発芽のセーフサイトに関す る知見を得た上で，種子をその場所に播種することが考えられる。 その際には，低温湿潤処理を施した種子を春の訪れの前に人為的 に散布することのみで十分に効果的な個体群復元が可能である。

\section{引用文献}

1) Araki, S. \& Washitani, I. (2000): Seed dormancy/germination traits of seven Persicaria species and their implication in soil seedbank strategy : Ecological Research 15, 33-46

2 ) Baskin, J.M. \& Baskin, C.C. (1985) : The annual dormancy cycle in buried weed seeds: a continuum : BioScience 35, 492-498

3 ) Baskin, J.M. \& Baskin, C.C. (1989) : Physiology of dormancy and germination in relation to seed bank ecology, 53-66 pp.: in Ecology of soil seed banks, Leck, M.A., Parker V.T. \& Simpson, R.L. ed. : Academic Press, 462 pp.

4) Chippindale, H.G. \& Milton, W.E.J. (1934) : On the viable seeds and observations on their natural dormancy : Journal of Ecology 22, 508-531

5 ) Cohen, D. (1966) : Optimizing reproduction in a randomly varying environment: Journal of Theoretical Biology 12, 119-129

6 ) Cohen, D. (1967) : Optimizing reproduction in a randomly varying environment when a correlation may exist between the conditions at the time a choice as to be made and the subsequent outcome : Journal of Theoretical Biology 16, 1-14

7 ) Dalling, J.W., Swaine, M.D. \& Garwood, N.C.G. (1994) : Effect of soil depth on seedling emergence in tropical soil seed-bank investigations : Functional Ecology 9, 119-121

8 ) Dessaint, F., Chadoeuf, R. \& Barralis, G. (1997) : Nine year's soil seed bank and weed vegetation relationships in an arable field without weed control : Journal of Applied Ecology 34, 123-130

9) Fenner, M. (1980a): The inhibition of germination of Bidens pilosa seed by leaf canopy shade in some natural vegetation types: New Phytologist 84, 95-101

10) Fenner, M. (1980b) : The induction of a light requirement in Bidens pilosa seeds by leaf canopy shade : New Phytologist 84, 103-106

11) Grime, J.P., Mason, G., Curtis, A.V., Rodman, J., Band, S.R., 
Mowforth, M.A.G., Neal, A.M. \& Shaw, S. (1981) : A comparative study of germination characteristics in a local flora : Journal of Ecology 69, 1017-1059

12) Gross, K.L. (1990): A comparison of methods for estimating seed numbers in the soil : Journal of Ecology 78, 1079-1093

13）浜田拓・倉本宣（1995）：実生出現法によるコナラ林の埋土種子集団 の研究及びその植生管理への応用：ランドスケープ研究 58(1), 76-82

14）服部保・田村和也・小舘誓治（2000）：フジバカマ生育地の現状と保 全：ランドスケープ研究 63, 477-480

15）本田裕紀郎・倉本宣（2001a）：多摩川に打ける絶滅危惧植物カワラニ ガナIxeris tamagawaensis Kitam.の生育地特性 : 環境システム研究 29, 97-102

16）本田裕紀郎・倉本宣（2001b）：多摩川における絶滅危惧植物カワラニ ガナの現状とその休眠・発芽特性：ランドスケープ研究 64, 583-588

17）今橋美千代・熟谷いづみ（1996）：土壤シードバンクを用いた河畔冠 水草原復元の可能性の検討 : 保全生態学研究 1, 131-147

18）環境庁編（2000）：改訂・日本の絶滅のおそれのある野生生物 [植物 I ], 660 pp.

19) Kalisz, S. \& McPeek, M.A. (1992) : Demography of an agestructured annual: Resampled projection matrices, elasticity analyses, and seed bank effects : Ecology 73, 1082-1093

20) Kalisz, S. \& McPeek, M.A. (1993) : Extinction dynamics, population growth and seed banks: An example using an age-structured annual : Oecologia 95, 314-320

21) King, T.J. (1975) : Inhibition of seed germination under leaf canopies in Arenaria serpyllifolia, Veronica arvensis and Cerastum holosteoides: New Phytologist 75, 87-90

22）倉本宣・本田裕紀郎・八木正徳（2000）：丸石河原固有植物と多摩川 に打けるその生育状況：明治大学農学部研究報告 123, 27-32

23）倉本宣・井上健（1996）：多摩川におけるカワラノギクの生育地の特 性についての研究 : ランドスケープ研究 59, 93-96

24）倉本宣・鷲谷いづみ・井上健（1995）：多摩川に打けるカワラノギク の個体群の分断化とその保全に扮ける種子散布の役割：ランドスケー プ研究 58(5), 113-116

25) Leck, M.A. \& Graveline K.J. (1979): The seed bank of a fresh water tidal marsh : American Journal of Botany 66, 1006-1015

26) Masuda, M., Maki, M. \& Yahara, T. (1999) : Effects of salinity and temperature on seed germination in a Japanese endangered halophyte Triglochin maritimum (Juncaginaceae) : Journal of Plant Research 112, 457-461

27) Masuda, M. \& Washitani, I. (1992) : Differentiation of spring emerging and autumn emerging ecotypes in Galium spurium L. var. echinospermon : Oecologia 89, 42-46

28) McGraw, J.B. (1980) : Seed bank size and distribution of seeds in cottongrass tussock tundra, Eagle Creek, Alaska : Canadian Journal of Botany 58, 1607-1611

29）牧野富太郎（2000）：小野幹雄・大場秀章・西田誠編 新訂牧野新日 本植物圖鑑：北隆館, $1452 \mathrm{pp}$.

30) Milberg, P. (1994) : Germination ecology of the endangered grassland biennial Gentianella campestris : Biological Conservation 70, 287-290

31) Moore, J.M. \& Wein, R.W. (1977) : Viable seed population by soil depth and potential site recolonization after disturbance : Canadian Journal of Botany 66, 169-172

32) Nishihiro, J., Araki, S., Fujiwara, N. \& Washitani, I. (2004): Germination characteristics of lakeshore plants under an artificially stabilized water regime: Aquatic Botany 79, 333-343

33) Pavlik, B.M., Nickrent, D.L. \& Howald, A.M. (1993) : The recovery of an endangered plant, I. Creating a new population of Amsinckia grandiflora: Conservation Biology 7, 510-526

34) Pons, T.L. (1991) : Induction of dark dormancy in seeds: its importance for the seed bank in the soil : Functional Ecology 5, 669675

35) Quinn, G.P. \& Keough, M.J. (2002) : Comparing groups or treatments - analysis of variance, 173-207 pp.: in Experimental De- sign and Data Analysis for Biologists : Cambridge University Press, $537 \mathrm{pp}$

36) Sheldon, J.C. \& Burrows, F.M. (1973) : The dispersal effectiveness of the achene-pappus units of selected Compositae in steady winds with convection: New Phytologist 72, 665-675

37) Shimono, A. \& Washitani, I. (2004): Seedling emergence patterns and dormancy/germination physiology of Primula modesta in a subalpine region : Ecological Research 19, 541-551

38) Silvertown, J.W. (1980) : Leaf-canopy-induced seed dormancy in a grassland flora: New Phytologist 85, 109-118

39) Spence, J.R. (1990) : Seed rain in grassland, herbfield, snowbank, and fellfield in the alpine zone, Craigiburn Range, South Island, New Zealand : New Zealand Journal of Botany 28, 439-450

40) Takenaka, A., Washitani, I., Kuramoto, N. \& Inoue, K. (1996) : Life history and demographic features of Aster kantoensis, an endangered local endemic of floodplains : Biological Conservation 78, 345-352

41) Thompson, K. (2000) : The functional ecology of soil seed banks, 215-235 pp.: in Seeds: the Ecology of Regeneration in Plant Communities, Fenner, M. ed. : CABI Publishing, 410 pp.

42) Thompson, K., Bakker, J.P., Bekker, R.M. \& Hodgson, J.G. (1998) : Ecological correlates of seed persistence in soil in the north-west European flora: Journal of Ecology 86, 163-169

43) Thompson, K. \& Grime, J.P. (1983) : A comparative study of germination responses to diurnally fluctuating temperatures: Journal of Applied Ecology 20, 141-156

44) Thompson, K., Grime, J.P. \& Mason, G. (1977) : Seed germination in response to diurnal fluctuations of temperature: Nature 267, 147-149

45) Thompson, K., Roberta, M.C., Bakker, J.P. \& Bekker, R.M. (2003) : Are seed dormancy and persistence in soil related? : Seed Science Research 13, 97-100

46）富沢美和・鷲谷いづみ（1998）：フジバカマとセイタカアワダチソウ の夏季における地上部喪失に対する反応一復元植生の管理計画を立て るために一：保全生態学研究 3, 57-67

47) Verkaar, H.J., Schenkeveld, A.J. \& Van der Klashorst, M.P. (1983) : The ecology of short-lived forbs in chalk grasslands: Dispersal of seeds : New Phytologist 95, 335-344

48) Wesson, G. \& Wareing, P.F. (1967) : Light requirements of buried seeds : Nature 213, 600-601

49) Wesson, G. \& Wareing, P.F. (1969): The induction of light sensitivity in weed seeds by burial : Journal of Experimental Botany 20, 414-425

50) Washitani, I. (1985) : Field fate of Amaranthus patulus seeds subjected to leaf-canopy inhibition of germination : Oecologia 66, 338-342

51) Washitani, I. (1987) : A convenient screening test system and a model for thermal responses of wild plant seeds: behaviour of model and real seeds in the system : Plant Cell and Environment 10, 587-598

52）鷲谷いづみ（1996）：休眠・発芽特性と土壤シードバンク調査・実験 法（連載第 1 回）：保全生態学研究 1, 89-98

53）鷲谷いづみ（1997）：休眠・発芽特性と土壌シードバンク調査・実験 法（連載第 3 回）：保全生態学研究 2, 77-85

54) Washitani, I. (2001) : Plant conservation ecology for management and restoration of riparian habitats of lowland Japan : Population Ecology 43, 189-195

55) Washitani, I. \& Masuda, M. (1990) : A comparative study of the germination characteristics of seeds from a moist tall grassland community : Functional Ecology 4, 543-557

56) Washitani, I., Takenaka, A., Kuramoto, N. \& Inoue, K. (1997): Aster kantoensis Kitam., an endangered flood plain endemic plant in Japan: its ability to form persistent soil seed banks : Biological Conservation 82, 67-72 